\title{
Disaggregated Energy Consumption and Sectoral Outputs in Thailand: ARDL Bound Testing Approach
}

\author{
Thurai Murugan Nathan * Venus Khim-Sen Liew ${ }^{\dagger} \quad$ Wing-Keung Wong ${ }^{\ddagger}$
}

\begin{abstract}
From an economic perspective, energy-output relationship studies have become increasingly popular in recent times, partly fuelled by a need to understand the effect of energy on production outputs rather than overall GDP. This study dealt with disaggregated energy consumption and output of some major economic sectors in Thailand. ARDL Bound Testing approach was employed to examine the co-integration relationship. The Granger causality test of the aforementioned ARDL framework was done to investigate the corresponding causality effect. Results showed that, from year 1980 to 2010, productivity of most scrutinized industries was highly reliant on crude oil and natural gas. However, coal usage in transportation and agricultural industries can be reduced without affecting productivity. Few recommendations are given thereafter for Thailand to better manage their imported and local energy sources.
\end{abstract}

Keywords: Sectoral outputs, disaggregated energy consumption, ARDL Bound testing, Thailand, economic growth.

\section{Introduction}

Presently, the interest and attention on energy studies have been increased among researchers in order to address the problems caused by repetitive occurrence of energy crises since the first oil shock in the early 1970s (particularly in 1973 and 1979) until the recent massive drop in oil prices. Such crises have substantially heightened many countries' energy bill and affected the nations' productivity growth, causing energy sources to become one of the major growth constraints in term of output growth. This setback, in particular, has motivated numerous researchers to focus on energy-outputs relationship studies rather than the common energy-GDP study, such as Liew, Nathan, and Wong (2012); Costantini and Martini (2010); Ghali and El-Sakka (2004); Collard, Fève, and Portier (2005). Liew et al. (2012) specified that the advantage in investigating the energy-output relationship is to specifically pinpoint the dependency of other sectors on the energy sector in a particular country. In relation to this and taking a step further, this study is contributing to the existing literature through the introduction of a new approach in disaggregating the overall energy sector into sub-energy sectors to provide a more precise picture on the dependency of economy sectors according to specific type of energy.

\footnotetext{
*Lecturer, Faculty of Business and Finance, Department of Economics, Universiti Tunku Abdul Rahman, Malaysia. E-mail: thurai@utar.edu.my

$\dagger$ Associate Professor, Department of Economics, Universiti Malaysia Sarawak. Kuching, Malaysia. E-mail: ksliew@feb.unimas.my

$\ddagger$ Professor, Department of Economics, Hong Kong Baptist University. Hong Kong.

E-mail: awong@hkbu.edu.hk
} 
This study has chosen Thailand as the target since the nation's GDP growth has been increasing after the stock market recovered from the 1997-1998 Asian financial crisis. At the same time, according to the Department of Alternative Energy Development and Efficiency (2004) the energy consumption in many economic sectors in Thailand is also increasing. This means that the country will benefit from having good energy policies in place to strengthen the country's GDP growth before the economy is hampered by another economic crisis. This is also in view of the fact that energy accessibility and consumption play vital roles in production and output growth, and thus considerable attention has been placed on identifying energy-outputs relationship in Thailand.

This study has also contributed in terms of the application of the Autoregressive Distributive Lag (ARDL) bound testing approach developed by Pesaran and Shin (1998); Pesaran, Shin, and Smith (2001) in identifying the pertaining co-integration relationship. ARDL test has two advantages over the commonly used Johansen co-integration test; (1) it can overcome the problems often encountered with small sample sizes (Pesaran \& Shin, 1998; Raza, 2015) and (2) it omits the necessity to examine the non-stationarity property and order of integration (variables integrated at $\mathrm{I}(1), \mathrm{I}(0)$ or a mixture of both are acceptable). This study also utilized the WALD test of ARDL framework to identify the causality effect between the disaggregated energy consumption and selected sectoral outputs.

The results of the study showed that different sectors are reliant on different types of energy. The causality results indicated that sectors such as industrial and services are highly reliant on the energy sector in Thailand. The outcome of this study shall be presented in the following order: the second section briefly discuss the four types of testable hypothesis in energy-output relationship analysis; Section 3 discusses the methodology and data adopted; Section 4 presents the results, while section 5 concludes the study. The appendix offers the stability test for the regression.

\section{Literature Review}

Generally, the findings of energy-output studies can be illustrated in four situations in the causality term. Nevertheless, in general, the identification of the direction of causality relationship between energy and outputs is the most important to allow policy restructuring. The relationship was initially introduced by Kraft and Kraft (1978) and later on, Apergis and Payne (2010) categorized it into four testable hypotheses, i.e. growth, conservation, feedback, and neutrality hypothesis. The growth hypothesis implies that energy consumption is crucial to the outputs' growth, and can be identified using the unidirectional causality relationship that runs from energy consumption towards the relevant outputs (Apergis \& Payne, 2010; Costantini \& Martini, 2010; Ho \& Siu, 2007). If otherwise, it means that energy protection policies can be implemented without harming the performance of the sector (conservation hypothesis) (Al-Iriani, 2006; Hatemi, Irandoust, et al., 2005). Meanwhile, the feedback hypothesis indicates that energy consumption and outputs are interdependent of each other and this is identified as the bidirectional causality (Esso, 2010; Tang, 2008; Altinay \& Karagol, 2005; Raza, 2015). So, this interdependent indicates that any changes in energy consumption or sectoral outputs going to affect each other's. Finally, the neutrality hypothesis holds if there is no causality relationship between energy consumption and outputs (Ghorbani, Mansoori, \& Hamraz, 2009; Chiou-Wei, Chen, \& Zhu, 2008). This hypothesis implies that any changes in energy consumption and sectoral outputs do not affect each other's performance in economy. These are the hypotheses that have often been used in published works and also taken as the fundamental of this study. 


\section{Methodology}

\section{Data Description}

This study used annual data recorded from 1980 to 2010 for the oil, coal and gas consumption of Thailand contributed by the U.S. Energy Information Administration (2011). Data on the sectoral outputs such as agricultural, industrial, services and transport outputs of Thailand were obtained from the United Nation (2011). Since the energy data were given in different unit for different energy, an energy converter had been used to standardize all values into Million British Thermal Unit (Mmbtu). Sectoral outputs were thus represented as the sum of outputs for all sub sectors by the values added up by respective sectors (Liew et al., 2012; Costantini \& Martini, 2010). To overcome the problem of heteroskedasticity, all variables were subsequently changed into logarithmic forms (Gujarati, 2009; Alam, Raza, Shahbaz, \& Abbas, 2015; Raza, Shahbaz, \& Paramati, 2016). More details of the data can be found in Table 1.

\section{Structural Break test (Zivot and Andrews model)}

Waheed, Alam, and Ghauri (2006) argued that the common conventional unit root test such as ADF, DF-GLS and PP test cannot check for the possibility of structural break in the data set. Identifying the structural breaks in the data is important since it could lead to biasness in the estimation (Allaro, Kassa, \& Hundie, 2011). Accordingly, model without trend and with intercept is chosen for the estimation ${ }^{1}$.

$$
\Delta \ln Y_{t}=c+\alpha \ln Y_{t-1}+\beta t+\gamma D U_{t}+\sum_{j=1}^{k} d_{j} \Delta \ln Y_{t-j}+\epsilon
$$

Where $D U_{t}$ is an indicator, dummy variable for a mean shift occurring at each possible breakdata (BD). In formal terms,

$$
D U_{t}=\left\{\begin{array}{l}
1 \ldots \ldots \ldots \text { if } t>\mathrm{BD} \\
0 \ldots \ldots \ldots \text { otherwise }
\end{array}\right.
$$

The null hypothesis is $\alpha=0$, which implies that the series $\ln Y_{t}$ contains a unit root without structural break. The alternative hypothesis $\alpha<0$ implies that the series has a stationary process with one-time break occurring at an unknown point in time (Waheed et al., 2006).

\section{Co-integration test}

An ARDL model uses the lags of the dependent variable and the lags of independent variables to identify the short-run effect and long-run equilibrium relationship. In this study, the ARDL model has been estimated using the following unrestricted error correction model:

$$
\Delta \ln Y_{t}=\alpha+\sum_{i=0}^{k_{1}} \beta_{0} \Delta \ln X_{t-1}+\sum_{i=1}^{k_{2}} \beta_{1} \Delta \ln Y_{t-1}+\delta_{o} \ln X_{t-1}+\delta_{1} \ln Y_{t-1}+\epsilon_{t}
$$

\footnotetext{
${ }^{1}$ Zivot and Andrews model divided into 3 types i.e. with intercept only (Model 1), with trend only (Model 2) and with intercept and trend (Model 3). The model is chosen based on the nature of the data set.
} 


$$
\Delta \ln X_{t}=\varphi+\sum_{i=0}^{k_{1}} \mu_{0} \Delta \ln Y_{t-1}+\sum_{i=1}^{k_{2}} \mu_{1} \Delta \ln X_{t-1}+\delta_{o} \ln X_{t-1}+\delta_{1} \ln Y_{t-1}+\mu_{t}
$$

where $\mathrm{Y}$ and $\mathrm{X}$ stand for type of energy consumption and sectoral output, respectively; $\mathrm{k}_{-} 1$ and $\mathrm{k}_{-} 2$ represent the lag lengths; and $\epsilon_{t}$ and $\mu_{t}$ are white noise error terms. The co-integration relationships are sequentially examined using the Wald test (F-test). The null hypothesis of no co-integration among variables for Eq. (3) and (4) are $H_{o}: \delta_{0}=\delta_{1}=0$ and $H_{o}: \sigma_{0}=\sigma_{1}=0$ respectively, which are against $H_{1}: \delta_{0} \neq \delta_{1} \neq 0$ and $H_{1}: \sigma_{0} \neq \sigma_{1} \neq 0$. Decision to accept and reject the null hypothesis is based on the critical value provided by Pesaran et al. (2001). Finally, if a long-run relationship has been identified, then an error correction model within the ARDL model will be estimated using simple linear transformation.

Table 1

Data Descriptions in Detail

\begin{tabular}{|c|c|c|}
\hline Variables & Unit & Descriptions \\
\hline \multicolumn{3}{|c|}{ Data on energy consumption } \\
\hline Oil consumption & Thousand barrels per-day & $\begin{array}{l}\text { Total oil consumption includes internal con- } \\
\text { sumption; refinery fuel and loss; and bunker- } \\
\text { ing. Direct combustion of crude oil is included } \\
\text { if available. }\end{array}$ \\
\hline Gas consumption & Billion cubic Feet & Dry natural gas \\
\hline Coal consumption & Million short tons & $\begin{array}{l}\text { Coal consumption includes anthracite, sub- } \\
\text { anthracite, bituminous, sub-bituminous, lig- } \\
\text { nite, brown coal, and for Estonia, oil shale. } \\
\text { It also includes net imports of metallurgical } \\
\text { coke. }\end{array}$ \\
\hline \multicolumn{3}{|c|}{ Data on sectoral outputs } \\
\hline $\begin{array}{l}\text { Agricultural outputs } \\
\text { Industrial outputs }\end{array}$ & Billions & $\begin{array}{l}\text { Include agriculture, hunting, forestry, and } \\
\text { fishing activities. }\end{array}$ \\
\hline $\begin{array}{l}\text { Industrial outputs } \\
\text { Services outputs }\end{array}$ & (U.S constant 2005 price) & $\begin{array}{l}\text { Industry activities } \\
\text { Include wholesale, retail trade, restaurants, } \\
\text { and hotels. }\end{array}$ \\
\hline Transportation outputs & & $\begin{array}{l}\text { Include transport, storage and communication } \\
\text { activities. }\end{array}$ \\
\hline
\end{tabular}

\section{Causality test}

The causality relationships among all variables are examined using the Granger Causality Test. The following illustrates the model used to investigate the Granger causality between co-integrated variables, transformed from Eq. (3) and (4):

$$
\begin{aligned}
& \Delta \ln Y_{t}=\alpha+\sum_{i=1}^{k_{1}} \beta_{0} \Delta \ln Y_{t-i}+\sum_{i=1}^{k_{2}} \beta_{1} \Delta \ln X_{t-i}+\vartheta_{0} E C T_{t-1}+\epsilon_{t} \\
& \Delta \ln X_{t}=\varphi+\sum_{i=1}^{k_{1}} \mu_{0} \Delta \ln X_{t-i}+\sum_{i=1}^{k_{2}} \mu_{1} \Delta \ln Y_{t-i}+\omega_{0} E C T_{t-1}+\mu_{t}
\end{aligned}
$$

The causality effect is measured using the WALD test (F-statistics) ARDL framework where $H_{0}=\beta_{1}$ and $H_{0}=\mu_{1}$ for all $i$ in Eq. (5) and (6), respectively (Shahbaz, Awan, \& Nasir, 2009; 
Ozturk \& Acaravci, 2010; Keong, Yusop, \& Liew, 2005)²

\section{Empirical Results and Discussions}

Table 2 shows the results of Zivot and Andrews structural break test. The results suggest that the null hypothesis which states that the structural break has occurred in the data series can be reject at $10 \%$ significant level for coal consumption and services outputs, $5 \%$ significant level for all other sectoral outputs, and 1\% significant level for oil and gas consumption. To summarize, the most significant structural break in every series examined has been listed in Table 2, with all having important implications in term of policy reforming ${ }^{3}$.

Table 2

Zivot and Andrews Structural Breaks Test Results

\begin{tabular}{lccc}
\hline Variables & $\begin{array}{c}\text { Optimum } \\
\text { Lag (k) }\end{array}$ & t-statistics & Break Year \\
\hline Oil consumption & 1 & $-3.2623^{*}$ & 1989 \\
Gas consumption & 3 & $-5.1356^{*}$ & 2005 \\
Coal consumption & 5 & $-4.1956^{* * *}$ & 1998 \\
Agricultural outputs & 1 & $-3.2034^{* *}$ & 1996 \\
Services outputs & 1 & $-4.9604^{* * *}$ & 1995 \\
Industrial outputs & 1 & $-2.4601^{* *}$ & 1988 \\
Transportation outputs & 0 & $-2.4044^{* *}$ & 1989 \\
\hline Note: $\left(^{*}\right)$ (*) $^{*}$ and $(* * *)$ & denotes statistical significance at $10 \%, 5 \%$ \\
and 1\% level, respectively. & & \\
Source: Authors' Estimation &
\end{tabular}

Table 3

Bound Testing Results

\begin{tabular}{|c|c|c|c|c|c|c|c|}
\hline $\begin{array}{l}\text { Dependent } \\
\text { Variable }\end{array}$ & $\begin{array}{l}\text { Independent } \\
\text { Variable }\end{array}$ & $\begin{array}{l}\text { Optimum } \\
\text { Lag }\end{array}$ & $\begin{array}{l}\text { F-statistics } \\
{[\text { Prob }]}\end{array}$ & $\begin{array}{l}\text { Dependent } \\
\text { Variable }\end{array}$ & $\begin{array}{l}\text { Independent } \\
\text { Variable }\end{array}$ & $\begin{array}{l}\text { Optimum } \\
\text { Lag }\end{array}$ & $\begin{array}{l}\text { F-statistics } \\
\text { [Prob] }\end{array}$ \\
\hline LNOIL & LNAGR & 8 & $3.068[0.246]$ & LNGAS & LNIND & 7 & $19.20[0.005]^{*}$ \\
\hline LNARG & LNOIL & 7 & $0.724[0.530]$ & LNIND & LNGAS & 5 & $2.417[0.135]$ \\
\hline LNOIL & LNSER & 6 & $3.939[0.018]$ & LNGAS & LNTRA & 7 & $56.16[0.000]^{*}$ \\
\hline LNSER & LNOIL & 6 & $2.704[0.127]$ & LNTRA & LNGAS & 7 & $0.718[0.532]$ \\
\hline LNOIL & LNIND & 3 & $1.338[0.289]$ & & & & \\
\hline LNIND & LNOIL & 7 & $1.887[0.245]$ & LNCOAL & LNAGR & 6 & $1.879[0.214]$ \\
\hline LNOIL & LNTRA & 5 & $9.940[0.003]^{*}$ & LNAGR & LNCOAL & 7 & $0.183[0.838]$ \\
\hline \multirow{2}{*}{ LNTRA } & LNOIL & 5 & $2.526[0.125]$ & LNCOAL & LNSER & 5 & $2.348[0.142]$ \\
\hline & & & & LNSER & LNCOAL & 6 & $0.913[0.439]$ \\
\hline LNGAS & LNAGR & 4 & $4.028[0.023]$ & LNCOAL & LNIND & 5 & $5.977[0.017]^{* *}$ \\
\hline LNAGR & LNGAS & 6 & $2.656[0.130]$ & LNIND & LNCOAL & 5 & $4.315[0.041]$ \\
\hline LNGAS & LNSER & 5 & $1.869[0.200]$ & LNCOAL & LNTRA & 7 & $3.945[0.094]$ \\
\hline LNSER & LNGAS & 6 & $10.38[0.006]^{*}$ & LNTRA & LNCOAL & 7 & $0.418[0.680]$ \\
\hline
\end{tabular}

The Bound Testing results for various variable combinations are presented in Table 3. The

\footnotetext{
${ }^{2}$ Microfit 4.0 and Eviews statistical software were used for the results estimation.

${ }^{3}$ For further details, refer to study of (Waheed et al., 2006)
} 
optimum lag was chosen using the minimum value of the Schwarz-Bayesian Criterion (SBC). ${ }^{4}$ To make sure that the model was well-fitted, the selected optimum lag had been tested using diagnostic test for serial correlation, functional form, normality and heteroscedasticity.

Table 4

Long-run Coefficients, and Short-run Error-Correction Model

\begin{tabular}{|c|c|c|c|c|}
\hline Dependent variable & Regressor & Coefficient & Standard Error & t-ratio $[$ Prob] \\
\hline \multicolumn{5}{|c|}{ Panel A: Estimated long-run coefficients } \\
\hline \multirow[t]{2}{*}{ LNOIL $(1,1)$} & LNTRA & 1.206 & 0.046 & $26.214[0.000]$ \\
\hline & INPT & 12.513 & 0.105 & $118.815[0.000$ \\
\hline \multirow[t]{2}{*}{ LNSER $(6,6)$} & LNGAS & 0.484 & 0.029 & $16.977[0.000]$ \\
\hline & INPT & -6.790 & 0.623 & $-10.900[0.000]$ \\
\hline \multirow[t]{2}{*}{ LNGAS $(3,7)$} & LNIND & 1.098 & 0.144 & $7.611[0.000]$ \\
\hline & INPT & 16.849 & 0.724 & $23.279[0.000]$ \\
\hline \multirow[t]{2}{*}{ LNGAS $(4,0)$} & LNTRA & 1.368 & 1.353 & $1.011[0.326]$ \\
\hline & INPT & 18.415 & 4.235 & $4.349[0.000]$ \\
\hline \multirow[t]{2}{*}{ LNCOAL $(1,0)$} & LNIND & 1.043 & 0.060 & $17.438[0.000]$ \\
\hline & INPT & 16.595 & 0.239 & $69.444[0.000]$ \\
\hline \multicolumn{5}{|c|}{ Panel B: Error-correction representation for the selected ARDL model } \\
\hline \multirow[t]{3}{*}{$\Delta$ LNOIL $(1,1)$} & $\triangle$ LNTRA & 0.474 & 0.074 & $6.398[0.012]$ \\
\hline & $\Delta \mathrm{INPT}$ & 4.913 & 0.708 & $6.943[0.000]$ \\
\hline & $\mathrm{EC}_{t}$ & -0.393 & 0.057 & $-6.862[0.000]$ \\
\hline \multirow[t]{8}{*}{$\Delta \operatorname{LNSER}(6,6)$} & $\Delta$ LNGAS $_{t}$ & 0.245 & 0.421 & $0.582[0.572]$ \\
\hline & $\Delta \mathrm{LNGAS}_{t-1}$ & 0.546 & 0.361 & $1.512[0.159]$ \\
\hline & $\Delta \mathrm{LNGAS}_{t-2}$ & 0.587 & 0.236 & $2.483[0.030]$ \\
\hline & $\Delta \mathrm{LNGAS}_{t-3}$ & 0.675 & 0.266 & $2.537[0.028]$ \\
\hline & $\Delta \mathrm{LNGAS}_{t-4}$ & -0.41 & 0.226 & $-1.816[0.097]$ \\
\hline & $\Delta \mathrm{LNGAS}_{t-5}$ & -0.027 & 0.014 & $-1.997[0.071]$ \\
\hline & $\Delta \mathrm{INPT}$ & -9.463 & 3.189 & $-2.967[0.013]$ \\
\hline & $\mathrm{EC}_{t}$ & -1.394 & 0.452 & $-3.082[0.010]$ \\
\hline \multirow[t]{9}{*}{$\triangle$ LNGAS $(3,7)$} & $\Delta \mathrm{LNIND}_{t}$ & -0.147 & 0.266 & $-0.553[0.590]$ \\
\hline & $\Delta \mathrm{LNIND}_{t-1}$ & -0.565 & 0.264 & $-2.143[0.053]$ \\
\hline & $\Delta \mathrm{LNIND}_{t-2}$ & -0.086 & 0.245 & $-0.353[0.730]$ \\
\hline & $\Delta \mathrm{LNINDt}_{t-3}$ & -0.633 & 0.248 & $-2.552[0.025$ \\
\hline & $\Delta \mathrm{LNIND}_{t-4}$ & -0.549 & 0.282 & $-1.950[0.075$ \\
\hline & $\Delta$ LNIND $_{t-5}$ & -0.539 & 0.270 & $-1.998[0.065]$ \\
\hline & $\Delta \mathrm{LNIND}_{t-6}$ & -0.384 & 0.269 & $-1.428[0.179]$ \\
\hline & $\Delta \mathrm{INPT}$ & 7.333 & 1.637 & $4.479[0.001]$ \\
\hline & $\mathrm{EC}_{t}$ & -0.435 & 0.112 & $-3.894[0.002]$ \\
\hline \multirow[t]{3}{*}{$\Delta$ LNGAS $(4,0)$} & $\Delta$ LNTRAt & 0.094 & 0.143 & $0.659[0.519]$ \\
\hline & $\Delta \mathrm{INPT}$ & 1.270 & 0.707 & $1.795[0.090]$ \\
\hline & $\mathrm{EC}_{t}$ & -0.069 & 0.048 & $-1.450[0.165]$ \\
\hline \multirow[t]{3}{*}{$\triangle \operatorname{LNCOAL}(1,0)$} & $\Delta \mathrm{LNINDt}$ & 0.722 & 0.129 & $5.604[0.000]$ \\
\hline & $\Delta \mathrm{INPT}$ & 11.492 & 1.454 & $7.905[0.000]$ \\
\hline & $\mathrm{EC}_{t}$ & -0.693 & 0.094 & $-7.353[0.000]$ \\
\hline
\end{tabular}

We use the f-statistics value to find the co-integration of all combinations of variables. The following table lists the combinations which have long-run relationship. This include oil consumption and transport outputs; services outputs and gas consumption; gas consumption and industrial outputs; gas consumption and transport outputs; and coal consumption and industrial outputs.

After this, the long-run coefficients (Panel A) and short-run error correction model (ECM)

\footnotetext{
${ }^{4} \mathrm{SBC}$ value is better than other model specification criteria since it fits small sample data (Ozturk \& Acaravci, 2010; Verma, 2007)
} 
(Panel B) of the ARDL model were estimated (Table 4). In this table, all the independent variables have a significant impact on dependent variables except LNTRA. The long-run coefficient of transport outputs was 1.206 at a significance level of $1 \%$. It means that 1 percent of increase in transport output will increase the oil consumption by about 1.206 percent. Based on Panel B of Table 4, the estimated coefficient of $E C_{t}$ for oil consumption and transport outputs was -0.393 . This suggests that any deviation occurred will be corrected by $39 \%$ over the following year. Also, probability value of the t-ratio is less than 0.01 , implying that the selected co-integration is significant at $1 \%$ level. The long-run relationship for all other co-integrated variables can be interpreted similarly.

Table 5

ARDL Diagnostic Tests Result

\begin{tabular}{lccccc}
\hline $\begin{array}{l}\text { Dependent } \\
\text { Variable }\end{array}$ & $\begin{array}{c}\text { Independent } \\
\text { Variable }\end{array}$ & $\begin{array}{c}\text { Serial } \\
\text { Correlation }^{a}\end{array}$ & $\begin{array}{c}\text { Functional } \\
\text { Form }^{b}\end{array}$ & Normality $^{c}$ & Heteroscedasticity $^{d}$ \\
\hline LNOIL & LNTRA & $1.047[0.306]$ & $0.025[0.875]$ & $0.740[0.691]$ & $0.210[0.647]$ \\
LNSER & LNGAS & $3.829[0.050]$ & $1.174[0.279]$ & $3.863[0.145]$ & $1.269[0.260]$ \\
LNGAS & LNIND & $0.186[0.666]$ & $1.394[0.238]$ & $0.117[0.943]$ & $2.734[0.098]$ \\
LNGAS & LNTRA & $0.036[0.850]$ & $2.304[0.129]$ & $1.120[0.571]$ & $0.391[0.532]$ \\
LNCOAL & LNIND & $1.009[0.315]$ & $2.770[0.096]$ & $0.255[0.880]$ & $5.921[0.015]$ \\
\hline Notes: a Lagrange multiplier test of residual serial correlation. b Ramsey's RESET test using the \\
square of the fitted values. c Based on a test of skewness and kurtosis of residuals. d Based on the \\
regression of squared residuals on squared fitted values. \\
Source: Authors' Estimation
\end{tabular}

At the final stage, diagnostic tests (Table 5), cumulative sum tests (CUSUM) and cumulative sum of squares (CUSUMSQ) tests were conducted to identify the model's stability. Results demonstrated that the models are well-fixed and the CUSUM and CUSUMSQ results indicated that the parameters are stable throughout the sample period of 1980-2010 (refer to appendix, Table A1).

The WALD test done during the final stage identifies the short-run causality among all variables (see Table 6 for results). The null hypothesis is rejected if the probability value is less than the $5 \%$ significance level. The probability of oil consumption, not Granger-causing transport outputs was, 0.000. Also, the probability of transport outputs, not Granger-causing oil consumption, was 0.871 .

Therefore, it can be concluded that there is a unidirectional causality relationship running from oil consumption towards transport outputs in the short-run. With reference to the study done by (Altinay \& Karagol, 2005), an increase in oil consumption can be viewed as the prominent indicator of transport outputs growth. Such unidirectional causality relationship has also been found between gas consumption and agricultural outputs; services outputs and oil, gas, and coal; and finally coal consumption and industrial outputs.

Besides that, bidirectional causality exists between gas consumption and industrial outputs. Bidirectional causality relationship implies that both variables are resolute and affected at the same time (Masih \& Masih, 1998). On the other hand, there is no causality effect for oil and coal consumption towards agricultural outputs. 
Table 6

Granger Causality Test Results (Wald Test F-statistic)

\begin{tabular}{|c|c|c|c|}
\hline \multirow{2}{*}{ Null Hypothesis } & \multicolumn{2}{|c|}{ Wald Test } & \multirow{2}{*}{ Direction } \\
\hline & Chi-square & Prob & \\
\hline LNOIL does not Granger-cause LNAGR & 0.498 & 0.480 & - \\
\hline LNAGR does not Granger-cause LNOIL & 0.008 & 0.930 & - \\
\hline LNOIL does not Granger-cause LNSER & 0.003 & 0.954 & \\
\hline LNSER does not Granger-cause LNOIL & $4.469^{* *}$ & 0.035 & $\mathrm{OIL} \leftarrow \mathrm{SER}$ \\
\hline LNOIL does not Granger-cause LNIND & $15.048^{*}$ & 0.000 & $\mathrm{OIL} \rightarrow \mathrm{IND}$ \\
\hline LNIND does not Granger-cause LNOIL & $4.462^{* *}$ & 0.035 & $\mathrm{OIL} \leftarrow \mathrm{IND}$ \\
\hline LNOIL does not Granger-cause LNTRA & $40.935^{*}$ & 0.000 & $\mathrm{OIL} \rightarrow \mathrm{TRA}$ \\
\hline LNTRA does not Granger-cause LNOIL & 0.026 & 0.871 & - \\
\hline LNGAS does not Granger-cause LNAGR & $5.000^{* *}$ & 0.025 & $\mathrm{GAS} \rightarrow \mathrm{AGR}$ \\
\hline LNAGR does not Granger-cause LNGAS & 1.469 & 0.226 & - \\
\hline LNGAS does not Granger-cause LNSER & 0.386 & 0.534 & - \\
\hline LNSER does not Granger-cause LNGAS & $4.368^{* *}$ & 0.037 & $\mathrm{GAS} \leftarrow \mathrm{SER}$ \\
\hline LNGAS does not Granger-cause LNIND & $16.226^{*}$ & 0.000 & $\mathrm{GAS} \rightarrow \mathrm{IND}$ \\
\hline LNIND does not Granger-cause LNGAS & $12.785^{*}$ & 0.000 & GAS $\leftarrow$ IND \\
\hline LNGAS does not Granger-cause LNTRA & 0.435 & 0.510 & - \\
\hline LNTRA does not Granger-cause LNGAS & 0.498 & 0.481 & - \\
\hline LNCOAL does not Granger-cause LNAGR & 2.069 & 0.150 & - \\
\hline LNAGR does not Granger-cause LNCOAL & 0.042 & 0.837 & - \\
\hline LNCOAL does not Granger-cause LNSER & 5.507 & 0.019 & - \\
\hline LNSER does not Granger-cause LNCOAL & $3.928^{* *}$ & 0.047 & $\mathrm{COAL} \leftarrow \mathrm{SER}$ \\
\hline LNCOAL does not Granger-cause LNIND & $31.407^{*}$ & 0.000 & $\mathrm{COAL} \rightarrow \mathrm{IND}$ \\
\hline LNIND does not Granger-cause LNCOAL & 2.660 & 0.103 & \\
\hline LNCOAL does not Granger-cause LNTRA & 0.327 & 0.568 & - \\
\hline LNTRA does not Granger-cause LNCOAL & 0.692 & 0.405 & - \\
\hline
\end{tabular}

\section{Conclusion and Recommendation}

The main contribution of this study is in the disaggregation of energy consumption in accordance to sectoral outputs. The rapid growth in Thailand in term of productivity and energy has been the main motivation for this study. The data had been tested for structural break before the analysis was carried out. ARDL test was done to check for the co-integration among variables. WALD test was adopted for the causality test. For Thailand, the industrial and transportation sectors are driven by energy consumption. This indicates that the growth hypothesis holds and that the industrial and transportation sectors' growth in term of outputs is heavily reliant on the amount of energy consumed. Any energy shortfalls and crisis may have huge impact on the output of those sectors. According to the U.S. Energy Information Administration (2011) the highest energy consumed by Thailand was natural gas (34\%), followed by coal (33\%) in 2009. Moreover, the industrial sector was the major contributor to Thailand's GDP growth (43\% of overall GDP), followed by the services sector (19\% of overall GDP) (United Nation, 2011). Consistent supply that satisfies the demand of natural gas is crucial to increase the productivity of industrial and agricultural sectors while for the industrial sector, oil supply proves to be the main productivity driver. Simply to say, to encourage growth within the nation, the government needs to supply or explore more energy sources, particularly natural gas and oil.

According to the Department of Alternative Energy Development and Efficiency (2004) Thailand is a coal producer, but it also imports energy from other countries such as Indonesia $(65 \%$ of 
overall import), Vietnam, Myanmar, Australia, China, and Laos. Within the country, coal is used in two major productions-power sector (electricity production) and industrial sector. Statistically, Thailand can reduce the usage of coal in the agricultural and transport sectors without harming the respective production rates. This is because neutrality hypothesis holds for the agricultural and transportation sectors towards the coal consumption. This conserved energy resource can then be channeled to other sectors, primarily the industrial sector, to boost production growth. 


\section{References}

Alam, M. S., Raza, S. A., Shahbaz, M., \& Abbas, Q. (2015). Accounting for contribution of trade openness and foreign direct investment in life expectancy: The long-run and short-run analysis in Pakistan. Social Indicators Research, 1-16. doi: 10.1007/ s11205-015-1154-8

Al-Iriani, M. A. (2006). Energy-GDP relationship revisited: an example from GCC countries using panel causality. Energy policy, 34(17), 3342-3350.

Allaro, H. B., Kassa, B., \& Hundie, B. (2011). A time series analysis of structural break time in the macroeconomic variables in Ethiopia. African Journal of Agricultural Research, 6(2), 392-400.

Altinay, G., \& Karagol, E. (2005). Electricity consumption and economic growth: evidence from Turkey. Energy Economics, 27(6), 849-856.

Apergis, N., \& Payne, J. E. (2010). Renewable energy consumption and growth in Eurasia. Energy Economics, 32(6), 1392-1397.

Chiou-Wei, S. Z., Chen, C.-F., \& Zhu, Z. (2008). Economic growth and energy consumption revisited-evidence from linear and nonlinear Granger causality. Energy Economics, $30(6), 3063-3076$.

Collard, F., Fève, P., \& Portier, F. (2005). Electricity consumption and ICT in the French service sector. Energy Economics, $27(3), 541-550$.

Costantini, V., \& Martini, C. (2010). The causality between energy consumption and economic growth: A multi-sectoral analysis using non-stationary cointegrated panel data. Energy Economics, 32(3), 591-603.

Department of Alternative Energy Development and Efficiency. (2004). Annual report 2004: Thailand's Energy Situation, Bangkok, Thailand.

Esso, L. J. (2010). Threshold cointegration and causality relationship between energy use and growth in seven African countries. Energy Economics, 32(6), 1383-1391.

Ghali, K. H., \& El-Sakka, M. I. (2004). Energy use and output growth in Canada: a multivariate cointegration analysis. Energy Economics, 26 (2), 225-238.

Ghorbani, M., Mansoori, H., \& Hamraz, S. (2009). Reinvestigation of Relationship Between Macroeconomic Indexes and Energy Consumption in Iran. Journal of Applied Sciences, 9(8), 1578-1582.

Gujarati, D. N. (2009). Basic econometrics (5th ed.). Tata McGraw-Hill Education.

Hatemi, A., Irandoust, M., et al. (2005). Energy consumption and economic growth in Sweden: A leveraged bootstrap approach, 1965-2000. International Journal of Applied Econometrics and Quantitative Studies, 2(4), 87-98.

Ho, C.-Y., \& Siu, K. W. (2007). A dynamic equilibrium of electricity consumption and GDP in Hong Kong: an empirical investigation. Energy Policy, 35(4), 2507-2513.

Keong, C. C., Yusop, Z., \& Liew, V. K. S. (2005). Export-led growth hypothesis in Malaysia: An investigation using Bounds test. Sunway Academic Journal, 2, 13-22.

Kraft, J., \& Kraft, A. (1978). Relationship between energy and GNP. Journal of Energy Development, 3(2), 85-97.

Liew, V. K., Nathan, T., T. M., \& Wong, W.-K. (2012). Are Sectoral Outputs in Pakistan Led by Energy Consumption? Economics Bulletin, 32(3), 2326-2331. 
Masih, A. M., \& Masih, R. (1998). A multivariate cointegrated modelling approach in testing temporal causality between energy consumption, real income and prices with an application to two Asian LDCs. Applied Economics, 30(10), 1287-1298.

Ozturk, I., \& Acaravci, A. (2010). The causal relationship between energy consumption and GDP in Albania, Bulgaria, Hungary and Romania: Evidence from ARDL bound testing approach. Applied Energy, 87(6), 1938-1943.

Pesaran, M. H., \& Shin, Y. (1998). An Autoregressive Distributed-lag Modelling Approach to Cointegration Analysis. Cambridge University Press.

Pesaran, M. H., Shin, Y., \& Smith, R. J. (2001). Bounds Testing Approaches to the analysis of level relationships. Journal of Applied Econometrics, 16(3), 289-326.

Raza, S. A. (2015). Foreign direct investment, workers' remittances and private saving in Pakistan: an ARDL bound testing approach. Journal of Business Economics and Management, 16(6), 1216-1234.

Raza, S. A., Shahbaz, M., \& Paramati, S. R. (2016). Dynamics of Military Expenditure and income Inequality in Pakistan. Social Indicators Research, 1-21. doi: 10.1007/ s11205-016-1284-7

Shahbaz, M., Awan, R. U., \& Nasir, N. M. (2009). Producer \& Consumer prices nexus: ARDL bounds testing approach. International Journal of Marketing Studies, 1(2), 78-89.

Tang, C. F. (2008). A re-examination of the relationship between electricity consumption and economic growth in Malaysia. Energy Policy, 36(8), 3077-3085.

United Nation. (2011). Retrieved from http://www.unstats.un.org/unsd/snaama/ dnltransfer .asp?fid=16

U.S. Energy Information Administration . (2011). Retrieved from http://www.eia.gov/ countries/country-data. cfm?fips=bm

Verma, R. (2007). Savings, Investment and Growth in India An Application of the ARDL Bounds Testing Approach. South Asia Economic Journal, 8(1), 87-98.

Waheed, M., Alam, T., \& Ghauri, S. P. (2006). Structural breaks and unit root: evidence from Pakistani macroeconomic time series. Available at SSRN 963958. Retrieved from https://www.researchgate.net/profile/Saghir_Ghauri/publication/ 24112761_Structural_Breaks_and_Unit_Root_Evidence_from_Pakistani _Macroeconomic_Time_Series/links/0a85e532a9ecd133d7000000.pdf 


\section{Appendix:}

Table 7

ARDL Stability Tests Result for Thailand

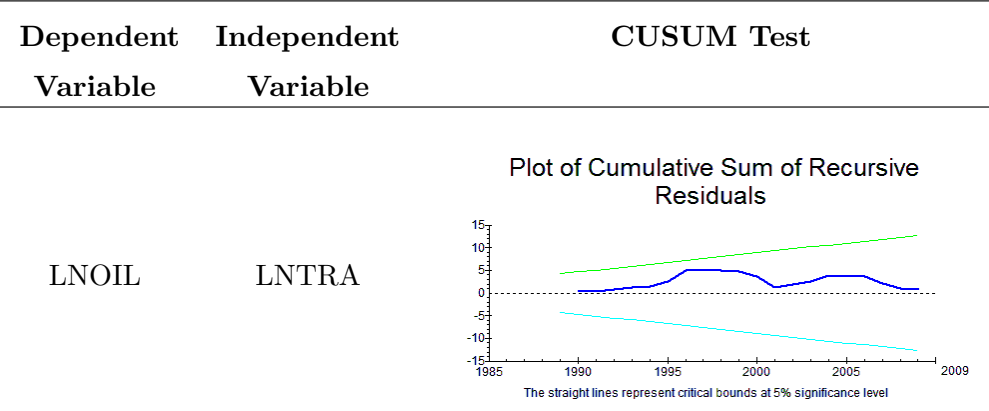

CUSUMSQ Test

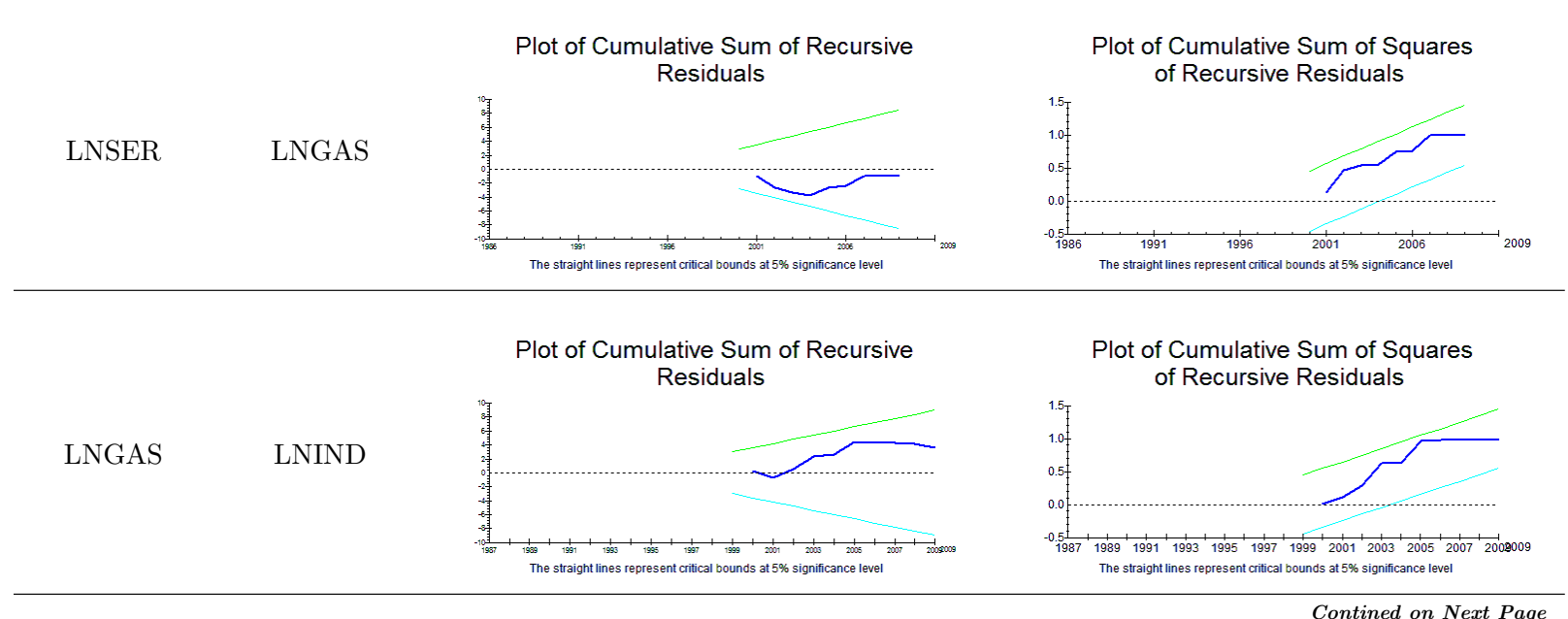

Plot of Cumulative Sum of Squares of Recursive Residuals

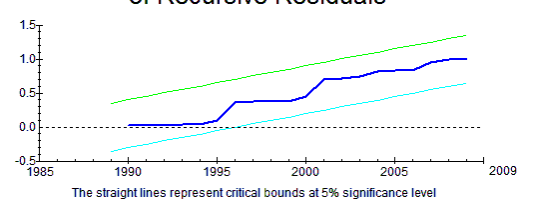


Continued from Previous Page

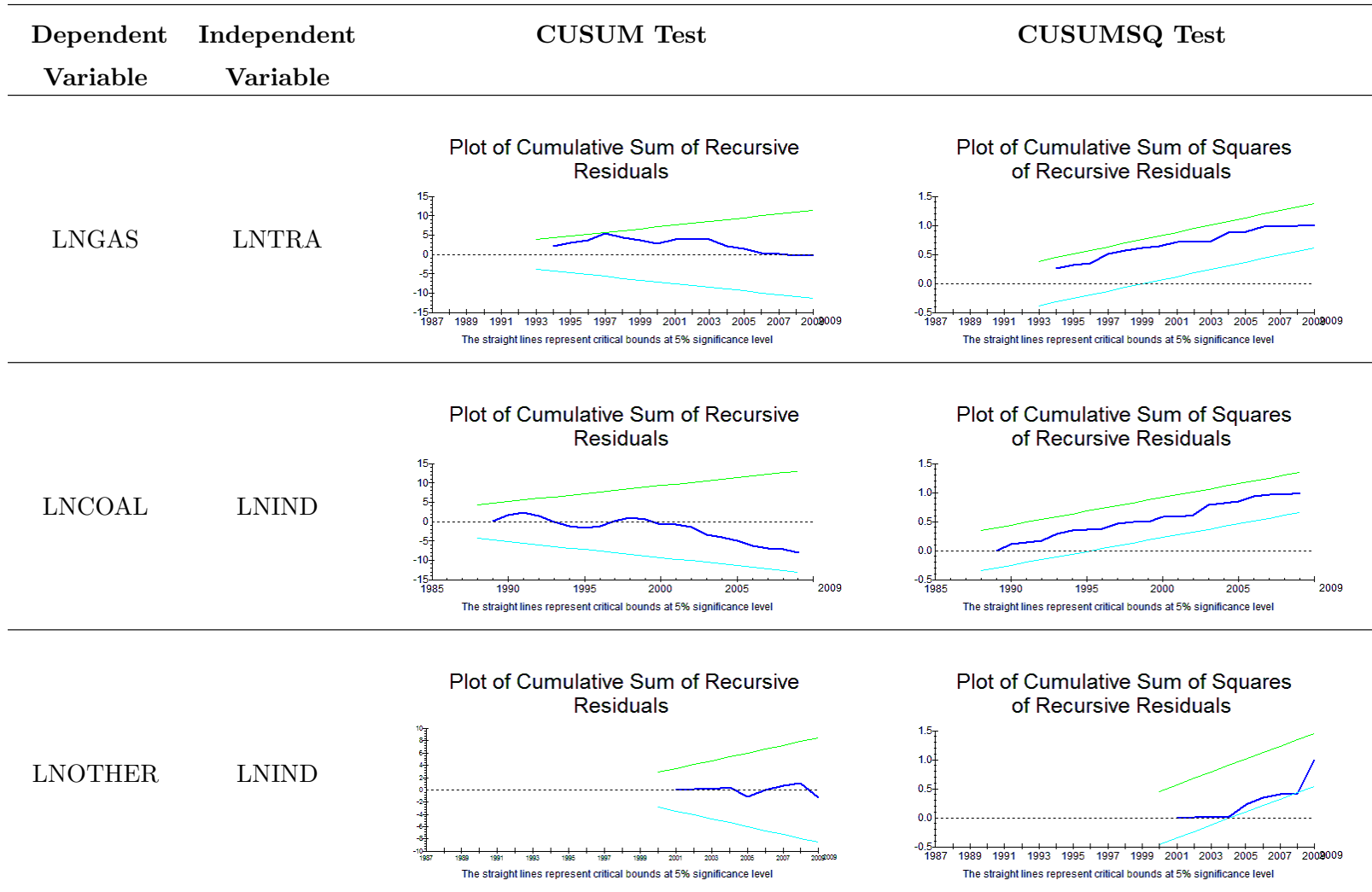

Notes: The illustration of CUSUM test and CUSUMSQ test has been generated from Microfit 4.1 and attached into the table. 